\title{
Empirical Paper
}

\section{Melik Ertugrul*, Ali Coskun \\ What is a real measure of corporate liquidity}

https://doi.org/10.2478/ijme-2021-0002

Received: May 20, 2020; accepted: January 21, 2021

\begin{abstract}
The financial health hypothesis argues that the valuation multiple of book value of equity (earnings) increases (decreases) as financial health decreases. By considering the liquidity dimension of financial health, we analyze an accrual-based liquidity ratio (current ratio) and a cash-based liquidity ratio (OCF ratio) from the perspective of this hypothesis. Using the median values of these ratios, we divide the sample consisting of listed firms on Borsa Istanbul during 2009-2018 into two and document the ensuing outcomes. Valuation multiples of book value of equity and earnings are reported as being statistically indifferent between low-liquid and high-liquid subgroups obtained for the median current ratio. However, the valuation multiple of book value of equity (earnings) significantly increases (decreases) for the low-liquid subgroup below the median OCF ratio. As the latter is consistent with the financial health hypothesis, this study reveals that the OCF ratio is a more convenient and reliable measure of liquidity than the current ratio.
\end{abstract}

Keywords: cash flow statement, current ratio, financial health, liquidity, operating cash flows

JEL Classification: G14, M21, M41

\section{Introduction}

As an aftermath of the global financial maelstrom and the recent global monetary contraction, finding external financing has become more challenging, which has made creditors more prudent [Tibor and Veronika, 2011]. Although defining liquidity is more difficult than recognizing it [Crockett, 2008], it may be considered as the repayment capability of current obligations with current assets [Richards and Laughlin, 1980]. Inconvenient liquidity evaluations may result in financial distress, which should be read as an eventual default risk [Richards and Laughlin, 1980]; for this reason, the liquidity of a firm should be closely monitored. From this perspective, liquidity ratios are analyzed under solvency ratios [Joseph, 2013] and they are indicators of financial health.

Dichev and Skinner [2002] and Chava and Roberts [2008] reveal that the current ratio is the most utilized debt covenant among other liquidity measures since it is standardized and involves no calculationcomplexity. In other words, it is calculated by dividing a sum (current assets) by another sum (current liabilities), and the calculation is very straightforward and unambiguous. However, this ratio is criticized since it is a static measure [Błach, 2010] which is an outcome of accrual-based accounting. Mills and Yamamura [1998] assert that the cash flow statement (CFS), which is obtained by cash-based accounting rules, provides more reliable information for the liquidity condition of a firm than traditional financial statements, which are the balance sheet and the income statement. CFS includes three main sections: cash flow from operations (OCF), cash flow from investments, and cash flow from financing. Since OCF reveals the cash generation capacity of a firm from its business activities, OCF figures are direct proxies for the

*Corresponding author: Melik Ertugrul, Department of Business Administration, Galatasaray University, Istanbul, Turkey.

E-mail: mertugrul@gsu.edu.tr

Ali Coskun, Department of Management, Bogazici University, Istanbul, Turkey. E-mail: ali.coskun@boun.edu.tr

We are very grateful for the precious support of Fatih Kiraz. 
ability to meet financial obligations [Al-Attar and Hussein, 2004]. By replacing the nominator part of the current ratio with OCF, the OCF ratio is obtained. As this ratio utilizes two-sum figures, which are OCF and current liabilities, it is easy to calculate from the perspective of Chava and Roberts [2008].

Altogether, both the OCF ratio and the current ratio utilize sums, which refer to their calculation simplicity, and they track the firm's capacity of meeting short-term obligations. The difference between these ratios is that the former (latter) reflects cash (accrual)-based accounting rules. As discussed, since one dimension of financial health is liquidity, these ratios convey a message related to financial health: the lower these ratios are, the lower is financial health. In this study, we analyze the valuationeffectiveness of these two liquidity measures from the perspective of the financial health hypothesis (FHH), which was proposed by Barth et al. [1998]. FHH simply argues that as financial health deteriorates, the valuation dominance of the financial position table increases while the valuation dominance of the financial performance table decreases. In general, book value of equity (earnings) is used as a part of the financial position (performance) statement in the firm valuation since both book value of equity and earnings provide a complementary contribution to market value of equity in realistic market settings with imperfections [Burgstahler and Dichev, 1997].

Empirical accounting research analyzes accounting quality from different perspectives [Wysocki, 2009], one of which is the value relevance. The value relevance is further one of the common subcategories of the capital markets-based accounting research classifications of Beaver [2002] and Kothari [2001]. As implied by the name of this research stream, the value relevance analyzes the statistical relationship between financial statement items and market figures [Francis and Schipper, 1999]. If the impact of a financial statement item on stock prices or returns is reported as statistically significant, this item is termed value relevant. As per FHH, the value relevance of book value of equity should be improved while the value relevance of earnings should be moderated by the low level of liquidity.

In this study, we investigate which liquidity ratio is considered to be a real liquidity measure by the market from the perspective of FHH. We shed light on which sum (the current ratio or the OCF ratio) conveys a message on the financial health of a firm to the market by analyzing the value relevance of book value of equity and earnings. To our knowledge, Barth et al. [1998] and Dhaliwal et al. [2010] analyze the impact of financial health on the value relevance of financial reporting items; however, they document evidence by considering debt ratings as an indicator of financial health. As underlined by Dhaliwal et al.[2010], this proxy may be a less reliable measure of financial health. In this study, we contribute to the literature in three significant ways. First, we show the value relevance implications of the low level of liquidity by considering it as a dimension of financial health indicator. Second, we document evidence to identify whether the sum obtained by accrual-based accounting rules or the sum obtained by cash-based accounting rules is considered to be real liquidity by the market. These two contributions may be of interest not only to investors using financial statements-based valuation models but also to lenders when they set liquidity-based debt covenants. Third, both Barth et al. [1998] and Dhaliwal et al. [2010] provide findings for local accounting standards-based financial statement items. Our study presents outcomes belonging to financial statement items prepared under International Financial Reporting Standards (IFRS). As IFRSbased financial reporting is necessary for all (or most) public companies in almost all jurisdictions, our last contribution may attract the interest of global financial reporting regulators, especially when developing new standards or amending the existing ones.

We test our hypotheses by analyzing listed firms on Borsa Istanbul during 2009-2018. First, as in Barth et al. [1998] and Dhaliwal et al. [2010], we divide the whole sample into two equal subsamples based on the median current ratio and we make the same division based on the median OCF ratio. Analyses based on the current ratio reveal that the impact of neither earnings nor book value of equity on stock prices does significantly differ between low-liquid and high-liquid subsamples. In other words, the value relevance of financial reporting items is independent of this type of low liquidity, which is not in line with FHH. Hence, from the perspective of $\mathrm{FHH}$, the market does not consider the current ratio as an indicator of the liquidity dimension of financial health. Analyses based on the OCF ratio show significant valuation implications: for the low-liquid subsample, the impact of earnings (book value of equity) on stock prices significantly declines (increases). To illustrate, for this type of low liquidity, the decreased (increased) pricing multiple 
of earnings (book value of equity) supports FHH. Therefore, from the perspective of FHH, the market does consider the OCF ratio as an indicator of the liquidity dimension of financial health. We also divide the whole sample into three, four, and five equal subsamples within each subsector based on both liquidity ratios and confirm these outcomes with minor exceptions. Finally, we conclude that the market (i) considers the cash-based and dynamic liquidity ratio, the OCF ratio, as a proxy for the liquidity dimension of financial health and (ii) does not consider the accrual-based and static liquidity ratio, the current ratio, as a proxy for the liquidity dimension of financial health.

The rest of this study is structured as follows. Section 2 provides the theoretical discussion. Section 3 describes the data and methodology. Section 4 discusses findings and Section 5 concludes this study by providing significant implications.

\section{Theoretical discussion}

The value relevance literature does not extensively focus on financial health; to our knowledge, there are two studies, which belong to Barth et al. [1998] and Dhaliwal et al. [2010], analyzing the impact of financial health on the value relevance of financial reporting information. Apart from them, several studies mention that they employ loss dummies as an indicator of financial health [as in Dhaliwal et al., 2010]. The information content of losses is more than that of profits [Hayn, 1995] and different valuation implications of valuation of losses should be taken into account in the value relevance research, as suggested by Chalmers et al. [2008]. However, the nature of loss figures is highly contentious because earnings are open to manipulation [Demir and Bahadır, 2007] which may spring from personal-mostly managerial-gains, the need for maintaining investor- and supplier-support, and meeting contractual targets [Lev, 2003]. Therefore, instead of setting a profitability requirement, Dichev and Skinner [2002] and Chava and Roberts [2008] directly focus on a standardized figure, which is the current ratio, as well as net asset worth, as a debt covenant restriction. Because of the contentious nature of losses, we do not present major findings of studies analyzing loss figures as a part of our discussion.

Based on a sample of US firms between 1975 and 1993, Barth et al. [1998] examine the impact of financial health on the value relevance of financial reporting information. They define financial health by considering bond ratings and employ financial health as follows: they directly use the bond rating if it is available and they predict the bond rating otherwise; thereafter, they divide their sample into two based on median bond ratings and they name the subgroup with lower ratings as the financially unhealthy subsample. Their outcomes reveal that, for the financially unhealthy subsample, the impact of book value of equity on stock prices significantly increases while the opposite holds for the impact of earnings. Moreover, for the financially unhealthy subsample, the pricing multiple of book value of equity (earnings) is almost doubled (halved). Barth et al. [1998] further report that, for financially unhealthy (healthy) firms, the incremental explanatory power of book value of equity is significantly greater (less) than the incremental explanatory power of earnings.

Based on a sample of US firms between 1989 and 1999, Dhaliwal et al. [2010] examine the association between financial health and the value relevance of financial reporting information by almost replicating the methodology of Barth et al. [1998]. Different from Barth et al. [1998], Dhaliwal et al. [2010] take senior and subordinated debt ratings into account and perform the same estimation procedure for unavailable ratings. By dividing their sample into two based on median bond ratings, they confirm the outcomes of Barth et al. [1998]: for the financially unhealthy subsample, the impact of book value of equity (earnings) on stock prices significantly increases (decreases). The decline in the pricing multiple of earnings is descriptively and notably greater for financially unhealthy firms grouped based on senior debt ratings compared to financially unhealthy firms grouped based on subordinated debt ratings. ${ }^{1}$ When Dhaliwal et al. [2010] add several items related to institutional ownership to their model, they confirm the increased valuation effect of book value of equity, while they document mixed outcomes for the valuation implications of earnings of financially unhealthy firms.

1 Dhaliwal et al. [2010] do not provide a statistical comparison. 
On the one hand, accrual-based accounting recognizes transactions when they are realized, independent of the timing cash inflow or outflow related to the corresponding transaction. On the other hand, cashbased accounting is directly dependent on the point in time when cash inflows or outflows take place. As per accrual-based accounting rules, many estimations must be performed under certain assumptions which evidently show management bias [Dechow et al., 2008]. Furthermore, accrual-based accounting rules yield understated (overstated) gains (losses) and assets (liabilities) under the concept of prudence [Elliott and Elliott, 2013]. Cash-based accounting does not include such subjectivities as it records a transaction when the corresponding receipt and payment take place. In other words, cash-based accounting directly tracks money and measures liquidity without any managerial biases toward future estimations. ${ }^{2}$ Elliott and Elliott [2013] underscore that since cash-based accounting contains only realized cash receipts and payments, it is more prudent than accrual-based accounting.

Compared to the traditional and familiar financial statements (the financial position table and the financial performance table), CFS is a relatively new financial statement, which makes CFS take less attention than it deserves [Hertenstein and McKinnon, 1997]. Among all financial statements, CFS is the only one that is presented in accordance with cash-based accounting rules. Since CFS directly tracks cash (both in forms of inflows and outflows), it reflects the liquidity condition of a firm in a more reliable manner than the traditional financial statements [Mills and Yamamura, 1998]. Mills and Yamamura [1998] further highlight that CFS depicts a dynamic picture of the way of utilizing the firm's resources.

The cash generation capacity of a firm's core business activities is revealed by the OCF section of CFS, and as underlined by Al-Attar and Hussein [2004], OCF is a good proxy for the ability to meet financial obligations. In line with Mills and Yamamura [1998], we argue that the OCF ratio (the nominator of which is a cash-based accounting item, OCF) reflects the liquidity condition of a firm better than the current ratio (the nominator of which is an accrual-based accounting item, current assets). We test this argument by considering the liquidity dimension of financial health within the FHH framework of Barth et al. [1998]. Barth et al. [1996] and Barth et al. [1998] reveal that the valuation multiple of earnings (book value of equity) decreases (increases) as financial health deteriorates or as a firm approaches liquidation. By arguing the superiority of the OCF ratio to the current ratio in measuring liquidity (and the liquidity dimension of financial health), we put forward the following hypotheses from the perspective of FHH:

Hypothesis 1: Valuation multiples of earnings and book value of equity do not depend on the liquidity dimension of financial health measured by the current ratio.

Hypothesis 2: Valuation multiples of earnings and book value of equity depend on the liquidity dimension of financial health measured by the OCF ratio.

\section{Data and methodology}

\subsection{Data}

Due to the following significant reasons, we select a sample of Turkish listed firms to perform our analyses. First, any national tinkering mechanism leading to impede the realization of the objectives of IFRS [Kvaal and Nobes, 2010] does not exist in the Turkish financial reporting environment because there is no local regulatory intervention during the implementation process of IFRS [Cagle et al., 2015]. In our period of analysis, since there is no local regulatory intervention inducing potential noise in accounting quality [Ertuğrul and Demir, 2018] and preventing the maximization of the benefits of IFRS, Turkish listed firms is convenient to test our hypotheses. Further, the stock market dynamics of Turkey make it very attractive for the value

2 Diamond [2002] discusses that cash-based accounting figures may also be manipulated and, hence, they are not necessarily superior to accrual-based accounting figures. In any case, in line with Chong [2012], we underline that cash-based accounting relies on receipts/payments and is therefore less open to manipulation. 
relevance analyses. The efficiency of Borsa Istanbul is highlighted in its Annual Integrated Report as follows: "Borsa Istanbul rounds off 2018 as the second most liquid platform in the world." [Borsa Istanbul, 2018, p. 4]. Note that the value relevance analyses are strictly dependent on stock market efficiency [Wyatt, 2008] and this trait makes the sample of Turkish listed firms appropriate for our research.

The sample of Turkish listed firms with available market values as of the end of March over 20102019 is employed in this study. Market values data are retrieved from Borsa Istanbul. We exclude financial institutions, holdings, and utilities as their regulatory reporting environment is distinctively different. We also exclude (i) watchlist observations due to their limited daily available trading period, (ii) observations with the fiscal year-end other than December, and (iii) observations with negative book value of equity figures as per going-concern related issues. Last, we hold the most liquid stock type and exclude the others if a firm has multiple listed shares. Then, we manually collect all necessary financial reporting data from the Public Disclosure Platform. The financial reporting data belongs to the period over 2009-2018 because the Price Model of Ohlson [1995] requires a one-year lag. Finally, if the financial statement of an observation is not available in the Public Disclosure Platform, that observation is also excluded. After all these filters, we have 2,329 firm-year observations belonging to 294 firms.

\subsection{Methodology}

Consistent with Barth et al. [1998] and Dhaliwal et al. [2010], the modified linear Price Model of Ohlson [1995] is employed in this study as shown in Eqs 1 and 2.

$$
\begin{aligned}
& \mathrm{P}_{\mathrm{i}, \mathrm{t}+1}=\beta_{0}+\beta_{1} \mathrm{xBVPS}_{\mathrm{i}, \mathrm{t}}+\beta_{2} \mathrm{xEPS}_{\mathrm{i}, \mathrm{t}}+\beta_{3} \mathrm{xDOCF}_{\mathrm{i}, \mathrm{t}}+\beta_{4} \mathrm{x} \mathrm{BVPS}_{\mathrm{i}, \mathrm{t}} \mathrm{x} \mathrm{DOCF}_{\mathrm{i}, \mathrm{t}}+\beta_{5} \mathrm{x} \mathrm{EPS}_{\mathrm{i}, \mathrm{t}} \mathrm{x} \mathrm{DOCF}_{\mathrm{i}, \mathrm{t}} \\
& \mathrm{P}_{\mathrm{i}, \mathrm{t}+1}=\beta_{0}+\beta_{1} \mathrm{xBVPS}_{\mathrm{i}, \mathrm{t}}+\beta_{2} \mathrm{x} \mathrm{EPS}_{\mathrm{i}, \mathrm{t}}+\beta_{3} \mathrm{x} \mathrm{DCUR}_{\mathrm{i}, \mathrm{t}}+\beta_{4} \mathrm{xBPS}_{\mathrm{i}, \mathrm{t}} \mathrm{x} \mathrm{DCUR}_{\mathrm{i}, \mathrm{t}}+\beta_{5} \mathrm{x} \mathrm{EPS}_{\mathrm{i}, \mathrm{t}} \mathrm{x} \mathrm{DCUR}_{\mathrm{i}, \mathrm{t}}
\end{aligned}
$$

In the above equations, $\mathrm{i}, \mathrm{t}, \mathrm{P}, \mathrm{BVPS}, \mathrm{EPS}$, DOCF, and DCUR, respectively, stand for firm, year, stock price measured after three months from the fiscal year-end, book value of equity per share, earnings per share, dummy obtained for the OCF ratio, and dummy obtained for the current ratio. Book value of equity is the remaining amount after deducing net income attributable to owners of the parent. Earnings are bottom-line net income figures. Note that all variables except for dummies are deflated by the number of shares outstanding to mitigate the scale effect problem from our regression outcomes. The OCF ratio is calculated by dividing cash flow from operations by current liabilities and the current ratio is calculated by dividing current assets by current liabilities. In line with Barth et al. [1998] and Dhaliwal et al. [2010], we divide the whole sample into two equal subsamples based on median figures of these liquidity ratios within each subsector and create dummy variables for the subsample with the lowest liquidity. We further divide the whole sample into three, four, and five equal subsamples based on the current ratio and the OCF ratio within each subsector if dividing the sample into two may not reflect the actual liquidity condition. Note that this method works as a robustness check for our hypotheses. Statistically insignificant $\beta_{4}$ and $\beta_{5}$ coefficients in Eq. 1 confirm our first hypothesis. If the $\beta_{4}\left(\beta_{5}\right)$ coefficient in Eq. 2 is reported as significantly positive (negative), our second hypothesis is confirmed.

Before performing the analyses, all non-dummy variables are winsorized at the top and bottom $1 \%$ to eliminate the overinfluence of outliers. Moreover, as we employ interaction terms, the presence of multicollinearity should be controlled by performing the variance inflation factor (VIF) analysis for each regression. All mean and individual VIF figures are notably smaller than the critical value of 10, which should be read as no statistically significant mechanical interdependencies among independent variables. Afterward, to determine the correct regression method, the Hausman Test is performed as suggested by Ertuğrul and Demir [2018] and Onali et al. [2017]. For each equation, the outcome of the Hausman Test strongly suggests using the fixed-effects method, which controls for the firm-level unobserved heterogeneity. As another dimension of unobserved heterogeneity is at the year level [Ertuğrul and Demir, 2018], we further control for this dimension by adding year dummies (regression coefficients of which are not presented in tables for brevity) to each equation. Last, to lessen the potential bias in standard errors induced by the 
serial correlation and the cross-sectional correlation, we cluster standard errors at the firm level and year level as suggested by Gow et al. [2010].

\section{Results}

\subsection{Descriptive analyses}

Panel A of Table 1 presents descriptive statistics. The median stock price is 3.51 TL whereas the median book value of equity is $2.19 \mathrm{TL}$, and the median earnings is $0.16 \mathrm{TL}$. Also, the minimum loss figure is 2.46 TL and our unreported statistics show that almost 30\% of total observations record losses. When the value of mean and median current ratio figures is above 1, this means that firms meet the minimum current ratio requirement of 1 . However, statistics belonging to the other liquidity measure indicate a different scenario: the mean (median) OCF ratio reveals that firms generate cash from their business activities, which is almost one fourth (eighth) of their current liabilities.

Panel B of Table 1 presents the correlation matrix. The correlation coefficients between stock prices and book value of equity together with earnings are found to be significantly positive. Interestingly, the correlation coefficient between stock prices and the current ratio is not reported as significant, which may give a logical ground to our first hypothesis. On the other hand, the correlation coefficient between stock prices and the OCF ratio is reported as significantly positive, which may be read as an affirmative signal for our second hypothesis. All other correlation coefficients are reported as significantly positive. Since certain correlation coefficients are reported as larger figures, they may indicate the presence of multicollinearity. As discussed previously, all VIF analyses indicate no statistically significant multicollinearity effect on regression outcomes.

\subsection{Multivariate analyses}

In Table 2, the first (second) column of each panel reveals the outcome for the lowest liquidity subsample based on the current (OCF) ratio. The lowest liquidity subsamples are obtained by dividing the whole

Table 1. Descriptive statistics and correlation matrix

\begin{tabular}{|c|c|c|c|c|c|c|}
\hline \multicolumn{7}{|l|}{ Panel A } \\
\hline & $\mathbf{N}$ & MEAN & P50 & SD & MIN & MAX \\
\hline $\mathbf{P}$ & 2,329 & 13.11 & 3.510 & 29.55 & 0.290 & 190 \\
\hline BVPS & 2,329 & 4.700 & 2.192 & 7.774 & 0.237 & 53.63 \\
\hline EPS & 2,329 & 0.554 & 0.164 & 1.551 & -2.464 & 9.404 \\
\hline CUR_R & 2,329 & 2.330 & 1.481 & 2.797 & 0.185 & 19.51 \\
\hline OCF_R & 2,329 & 0.255 & 0.124 & 0.897 & -3.053 & 4.914 \\
\hline \multicolumn{7}{|l|}{ Panel B } \\
\hline & $\mathbf{P}$ & BVPS & EPS & CUR_R & OCF_R & \\
\hline $\mathbf{P}$ & 1 & & & & & \\
\hline BVPS & $0.7932^{\star}$ & 1 & & & & \\
\hline EPS & $0.6687^{*}$ & $0.6237^{\star}$ & 1 & & & \\
\hline CUR_R & 0.0373 & $0.0534^{\star}$ & $0.1166^{\star}$ & 1 & & \\
\hline OCF_R & $0.1124^{\star}$ & $0.0987^{\star}$ & $0.1918^{\star}$ & $0.2691^{\star}$ & 1 & \\
\hline
\end{tabular}

Note: Panels A and B present descriptive statistics and correlation matrix. P, BVPS, EPS, CUR_R, and OCF_R stand for stock price measured after 3 months from the fiscal year-end, book value of equity, earnings, current ratio, and operating cash flow ratio. All variables except for ratios are deflated by the number of shares outstanding. N, MEAN, P50, SD, MIN, and MAX refer to the total number of observations, mean, median, standard deviation, minimum, and maximum.

${ }^{*} p<0.05$. 
Table 2. Regression analyses I

\begin{tabular}{|c|c|c|c|c|c|c|c|c|}
\hline & \multicolumn{2}{|c|}{ Panel A } & \multicolumn{2}{|c|}{ Panel B } & \multicolumn{2}{|c|}{ Panel C } & \multicolumn{2}{|c|}{ Panel D } \\
\hline & CUR_R & OCF_R & CUR_R & OCF_R & CUR_R & OCF_R & CUR_R & OCF_R \\
\hline BVPS & $\begin{array}{c}2.5069 * \star \star \\
(0.0000)\end{array}$ & $\begin{array}{c}2.3294^{\star \star \star} \\
(0.0000)\end{array}$ & $\begin{array}{c}2.5195^{\star \star \star} \\
(0.0000)\end{array}$ & $\begin{array}{c}2.3970 \star \star \star \\
(0.0000)\end{array}$ & $\begin{array}{c}2.4865^{\star \star \star} \\
(0.0000)\end{array}$ & $\begin{array}{c}2.3853^{\star \star \star} \\
(0.0000)\end{array}$ & $\begin{array}{c}2.4885^{\star \star \star} \\
(0.0000)\end{array}$ & $\begin{array}{c}2.4222^{\star \star \star} \\
(0.0000)\end{array}$ \\
\hline EPS & $\begin{array}{c}2.9678^{\star * \star} \\
(0.0014)\end{array}$ & $\begin{array}{c}4.0545^{\star \star \star} \\
(0.0001)\end{array}$ & $\begin{array}{c}3.0946 * \star \star \\
(0.0033)\end{array}$ & $\begin{array}{c}3.5681^{\star \star \star} \\
(0.0002)\end{array}$ & $\begin{array}{c}3.2280^{\star \star \star} \\
(0.0021)\end{array}$ & $\begin{array}{c}3.4692^{\star \star \star} \\
(0.0001)\end{array}$ & $\begin{array}{c}3.1020^{\star * *} \\
(0.0019)\end{array}$ & $\begin{array}{c}3.3031 * \star * \\
(0.0002)\end{array}$ \\
\hline D & $\begin{array}{c}1.0518 \\
(0.3236)\end{array}$ & $\begin{array}{c}0.1486 \\
(0.7970)\end{array}$ & $\begin{array}{l}1.7871^{\star} \\
(0.0958)\end{array}$ & $\begin{array}{l}-0.0329 \\
(0.9422)\end{array}$ & $\begin{array}{c}1.6955 \\
(0.1337)\end{array}$ & $\begin{array}{l}-0.4293 \\
(0.2819)\end{array}$ & $\begin{array}{l}2.0250^{\star} \\
(0.0895)\end{array}$ & $\begin{array}{l}-0.2485 \\
(0.7575)\end{array}$ \\
\hline BVPS $\times \mathrm{D}$ & $\begin{array}{l}-0.0385 \\
(0.8604)\end{array}$ & $\begin{array}{l}0.3960^{\star \star} \\
(0.0498)\end{array}$ & $\begin{array}{l}-0.2142 \\
(0.4678)\end{array}$ & $\begin{array}{l}0.2972^{*} \\
(0.0800)\end{array}$ & $\begin{array}{l}-0.1057 \\
(0.6990)\end{array}$ & $\begin{array}{l}0.4277^{\star \star} \\
(0.0480)\end{array}$ & $\begin{array}{l}-0.0340 \\
(0.9048)\end{array}$ & $\begin{array}{c}0.3595 \\
(0.1993)\end{array}$ \\
\hline$E P S \times D$ & $\begin{array}{l}-0.2768 \\
(0.7428)\end{array}$ & $\begin{array}{c}-2.8686^{\star \star} \\
(0.0107)\end{array}$ & $\begin{array}{l}-1.1641 \\
(0.3549)\end{array}$ & $\begin{array}{c}-2.6974^{\star \star} \\
(0.0148)\end{array}$ & $\begin{array}{l}-1.6146 \\
(0.2226)\end{array}$ & $\begin{array}{c}-2.8390 \star \star \\
(0.0196)\end{array}$ & $\begin{array}{l}-1.0609 \\
(0.3757)\end{array}$ & $\begin{array}{c}-2.9793^{* *} \\
(0.0142)\end{array}$ \\
\hline Constant & $\begin{array}{l}-0.7287 \\
(0.5751)\end{array}$ & $\begin{array}{l}-0.5818 \\
(0.6490)\end{array}$ & $\begin{array}{l}-0.7098 \\
(0.5680)\end{array}$ & $\begin{array}{l}-0.3334 \\
(0.7921)\end{array}$ & $\begin{array}{l}-0.6434 \\
(0.6181)\end{array}$ & $\begin{array}{l}-0.1795 \\
(0.8851)\end{array}$ & $\begin{array}{l}-0.6743 \\
(0.6099)\end{array}$ & $\begin{array}{l}-0.2034 \\
(0.8670)\end{array}$ \\
\hline Observations & 2,329 & 2,329 & 2,329 & 2,329 & 2,329 & 2,329 & 2,329 & 2,329 \\
\hline R-squared & 0.911 & 0.913 & 0.911 & 0.913 & 0.911 & 0.913 & 0.911 & 0.912 \\
\hline Firm FE & Yes & Yes & Yes & Yes & Yes & Yes & Yes & Yes \\
\hline Year FE & Yes & Yes & Yes & Yes & Yes & Yes & Yes & Yes \\
\hline
\end{tabular}

Notes: The dependent variable of each regression is stock price measured after 3 months from the fiscal year-end. Panels $A, B, C$, and D present outcomes obtained for dividing the entire sample into 2, 3, 4, and 5 equal subsamples based on the current ratio and the OCF ratio. The first (second) column of each panel documents outcomes for the interaction term between accounting items and the low-liquidity dummy obtained for the current (OCF) ratio. BVPS, EPS, CUR_R, and OCF_R, respectively, refer to book value of equity, earnings, current ratio, and operating cash flow ratio. All variables, except for dummies, are deflated by the number of shares outstanding. Firm-fixed and year-fixed effects are controlled. P-values are in parentheses.

${ }^{\star * *} p<0.01,{ }^{* *} p<0.05,{ }^{*} p<0.1$.

sample into two, three, four, and five subsamples, the outcomes of which are presented in Panels A, B, $\mathrm{C}$, and $\mathrm{D}$ of Table 2. As a general finding, in line with the extant literature providing evidence for Turkish listed firms in the IFRS implementation period, all regression coefficients of both book value of equity and earnings are reported as significantly positive, which refers to the value relevance of these items.

The first column of Panel A of Table 2 presents that interaction terms between the low-liquidity dummy and accounting items are not found as statistically significant for the subsample obtained for the current ratio. In other words, the impacts of both book value of equity and earnings on stock prices do not differ for observations which are grouped under the lowest liquidity subsample obtained for the current ratio. These findings are not in line with Barth et al. [1998] and Dhaliwal et al. [2010]. Since these outcomes show that valuation multiples of earnings and book value of equity do not depend on the liquidity dimension of financial health measured by the current ratio, our first hypothesis is confirmed: from the perspective of $\mathrm{FHH}$, the current ratio is not a good proxy for the liquidity dimension of financial health.

The second column of Panel A of Table 2 presents that interaction terms between the low-liquidity dummy and accounting items are reported as statistically significant for the subsample obtained for the OCF ratio. In other words, the impacts of both book value of equity and earnings on stock prices do differ for observations which are grouped under the lowest liquidity subsample obtained for the OCF ratio. Even more, for those observations, the valuation multiple of book value of equity which is equal to $2.7254(2.3294+0.3960)$ exceeds the valuation multiple of earnings which is equal to $1.1859(4.0545+(-2.8686))$. This gap becomes larger as the sample is divided into smaller subsamples. To illustrate, book value of equity becomes very dominant in the valuation of low-liquidity firms. Overall, in line with our expectations, these findings are consistent with Barth 
et al. [1998] and Dhaliwal et al. [2010], and they show that valuation multiples of earnings and book value of equity are dependent on the liquidity dimension of financial health measured by the OCF ratio.Thus, our second hypothesis is confirmed: from the perspective of FHH, the OCF ratio is a good proxy for the liquidity dimension of financial health.

Panels B, C, and D present outcomes which are obtained for dividing the whole sample into 3, 4, and 5 equal subsamples based on the current ratio and OCF ratio. In each panel, no interaction term between accounting items and the low-liquidity dummy obtained for the current ratio is reported as statistically significant, whereas all interaction terms between book value of equity (earnings) and the low-liquidity dummy obtained for the OCF ratio are reported as significantly positive (negative) with one exception. Moreover, book value of equity plays a more significant role in the valuation of low-liquidity (obtained for the OCF ratio) firms.

In Tables 3 and 4, we document further evidence to underpin the robustness of our outcomes by extending our analyses. First, as highlighted by Gómez-Rodríguez et al. [2012], the price-earnings association of profit observations is different than the price-earnings association of loss observations. Therefore, as suggested by Chalmers et al. [2008], we control for the differential valuation of losses by adding a loss dummy to each equation, and reperform all analyses, the outcomes of which are presented in Table 3. Second, the literature uses different deflators as factors for robustness analysis [Ertuğrul, 2019]. We use the current total assets figure [as in Xu et al., 2017; André et al., 2018] as a deflator, and reperform all analyses, the outcomes of which are presented in Table 4. With two exceptions, all these outcomes almost mirror those available in

Table 3. Regression analyses II

\begin{tabular}{|c|c|c|c|c|c|c|c|c|}
\hline & \multicolumn{2}{|c|}{ Panel A } & \multicolumn{2}{|c|}{ Panel B } & \multicolumn{2}{|c|}{ Panel C } & \multicolumn{2}{|c|}{ Panel D } \\
\hline & CUR_R & OCF_R & CUR_R & OCF_R & CUR_R & OCF_R & CUR_R & OCF_R \\
\hline BVPS & $\begin{array}{c}2.4948^{\star \star \star} \\
(0.0000)\end{array}$ & $\begin{array}{c}2.3223^{\star \star \star} \\
(0.0000)\end{array}$ & $\begin{array}{c}2.5098^{\star \star \star} \\
(0.0000)\end{array}$ & $\begin{array}{l}2.3889 * \star \star \\
(0.0000)\end{array}$ & $\begin{array}{c}2.4760 \star \star \star \\
(0.0000)\end{array}$ & $\begin{array}{c}2.3742^{\star \star \star} \\
(0.0000)\end{array}$ & $\begin{array}{c}2.4772 * \star \star \\
(0.0000)\end{array}$ & $\begin{array}{c}2.4103^{\star \star *} \\
(0.0000)\end{array}$ \\
\hline EPS & $\begin{array}{c}3.0578^{\star \star \star} \\
(0.0013)\end{array}$ & $\begin{array}{c}4.1315^{\star \star \star} \\
(0.0001)\end{array}$ & $\begin{array}{c}3.1723^{\star * *} \\
(0.0039)\end{array}$ & $\begin{array}{c}3.6572^{\star * *} \\
(0.0002)\end{array}$ & $\begin{array}{c}3.3147^{\star \star \star} \\
(0.0026)\end{array}$ & $\begin{array}{c}3.5815^{\star \star \star} \\
(0.0002)\end{array}$ & $\begin{array}{c}3.1992^{\star \star \star} \\
(0.0023)\end{array}$ & $\begin{array}{c}3.4253^{\star \star \star} \\
(0.0002)\end{array}$ \\
\hline D & $\begin{array}{c}0.8783 \\
(0.4079)\end{array}$ & $\begin{array}{c}0.1167 \\
(0.8346)\end{array}$ & $\begin{array}{c}1.6475 \\
(0.1328)\end{array}$ & $\begin{array}{l}-0.0558 \\
(0.9000)\end{array}$ & $\begin{array}{c}1.5299 \\
(0.1894)\end{array}$ & $\begin{array}{l}-0.4621 \\
(0.2417)\end{array}$ & $\begin{array}{c}1.8670 \\
(0.1254)\end{array}$ & $\begin{array}{l}-0.2721 \\
(0.7361)\end{array}$ \\
\hline BVPS $\times$ D & $\begin{array}{l}-0.0397 \\
(0.8560)\end{array}$ & $\begin{array}{l}0.3906^{*} \\
(0.0554)\end{array}$ & $\begin{array}{l}-0.2125 \\
(0.4748)\end{array}$ & $\begin{array}{l}0.2901^{\star} \\
(0.0891)\end{array}$ & $\begin{array}{l}-0.1032 \\
(0.7094)\end{array}$ & $\begin{array}{l}0.4240^{*} \\
(0.0502)\end{array}$ & $\begin{array}{l}-0.0304 \\
(0.9164)\end{array}$ & $\begin{array}{c}0.3575 \\
(0.2076)\end{array}$ \\
\hline$E P S \times D$ & $\begin{array}{l}-0.1643 \\
(0.8494)\end{array}$ & $\begin{array}{c}-2.8299 * \star \\
(0.0121)\end{array}$ & $\begin{array}{l}-1.0795 \\
(0.3741)\end{array}$ & $\begin{array}{c}-2.6454^{\star \star} \\
(0.0173)\end{array}$ & $\begin{array}{l}-1.5548 \\
(0.2265)\end{array}$ & $\begin{array}{c}-2.7938^{\star \star} \\
(0.0217)\end{array}$ & $\begin{array}{l}-1.0024 \\
(0.3898)\end{array}$ & $\begin{array}{c}-2.9309 * \star \\
(0.0183)\end{array}$ \\
\hline $\mathbf{L}$ & $\begin{array}{c}1.0247 \\
(0.1965)\end{array}$ & $\begin{array}{c}0.6951 \\
(0.3205)\end{array}$ & $\begin{array}{c}0.7749 \\
(0.1872)\end{array}$ & $\begin{array}{c}0.7673 \\
(0.2845)\end{array}$ & $\begin{array}{c}0.7863 \\
(0.1916)\end{array}$ & $\begin{array}{c}0.9012 \\
(0.2026)\end{array}$ & $\begin{array}{c}0.8297 \\
(0.1847)\end{array}$ & $\begin{array}{c}0.9526 \\
(0.2145)\end{array}$ \\
\hline Constant & $\begin{array}{l}-0.9547 \\
(0.4455)\end{array}$ & $\begin{array}{l}-0.7775 \\
(0.5319)\end{array}$ & $\begin{array}{l}-0.8993 \\
(0.4624)\end{array}$ & $\begin{array}{l}-0.5610 \\
(0.6474)\end{array}$ & $\begin{array}{l}-0.8398 \\
(0.5044)\end{array}$ & $\begin{array}{l}-0.4498 \\
(0.7056)\end{array}$ & $\begin{array}{l}-0.8948 \\
(0.4843)\end{array}$ & $\begin{array}{l}-0.4960 \\
(0.6714)\end{array}$ \\
\hline Observations & 2,329 & 2,329 & 2,329 & 2,329 & 2,329 & 2,329 & 2,329 & 2,329 \\
\hline R-squared & 0.911 & 0.913 & 0.911 & 0.913 & 0.912 & 0.913 & 0.911 & 0.912 \\
\hline Firm FE & Yes & Yes & Yes & Yes & Yes & Yes & Yes & Yes \\
\hline Year FE & Yes & Yes & Yes & Yes & Yes & Yes & Yes & Yes \\
\hline
\end{tabular}

Notes: The dependent variable of each regression is stock price measured after 3 months from the fiscal year-end. Panels A, B, C, and D present outcomes obtained for dividing the entire sample into 2, 3, 4, and 5 equal subsamples based on the current ratio and the OCF ratio. The first (second) column of each panel documents outcomes for the interaction term between accounting items and the low-liquidity dummy obtained for the current (OCF) ratio. BVPS, EPS, L, CUR_R, and $O C F \_R$, respectively, refer to book value of equity, earnings, loss dummy, current ratio, and operating cash flow ratio. Loss is a dummy variable which is equal to 1 if EPS is negative. All variables, except for dummies, are deflated by the number of shares outstanding. Firm-fixed and year-fixed effects are controlled. P-values are in parentheses.

${ }^{\star \star \star} p<0.01,{ }^{* \star} p<0.05,{ }^{*} p<0.1$. 
Table 4. Regression analyses III

\begin{tabular}{|c|c|c|c|c|c|c|c|c|}
\hline & \multicolumn{2}{|c|}{ Panel A } & \multicolumn{2}{|c|}{ Panel B } & \multicolumn{2}{|c|}{ Panel C } & \multicolumn{2}{|c|}{ Panel D } \\
\hline & CUR_R & OCF_R & CUR_R & OCF_R & CUR_R & OCF_R & CUR_R & OCF_R \\
\hline \multirow[t]{2}{*}{ BVPS } & $0.7063^{\star \star}$ & $0.5120^{\star}$ & $0.7182^{\star \star}$ & $0.5646^{\star}$ & $0.6997^{\star \star}$ & $0.5896^{\star}$ & $0.7273^{\star \star}$ & $0.5656^{\star}$ \\
\hline & $(0.0452)$ & $(0.0979)$ & $(0.0358)$ & $(0.0688)$ & $(0.0320)$ & $(0.0543)$ & $(0.0179)$ & $(0.0568)$ \\
\hline \multirow[t]{2}{*}{ EPS } & $1.7381^{\star \star \star}$ & $2.2798^{\star \star \star}$ & $1.8239^{\star \star \star}$ & $2.1087^{\star \star \star}$ & $1.7248^{\star \star \star}$ & $1.9182^{\star \star \star}$ & $1.6644^{\star \star \star}$ & $1.9560^{\star \star \star}$ \\
\hline & $(0.0011)$ & $(0.0003)$ & $(0.0006)$ & $(0.0002)$ & $(0.0007)$ & $(0.0008)$ & $(0.0007)$ & $(0.0005)$ \\
\hline \multirow[t]{2}{*}{ D } & -0.0345 & $-0.1657^{\star}$ & -0.0365 & $-0.1748^{\star}$ & -0.0803 & $-0.1787^{\star \star}$ & -0.0431 & $-0.2196^{\star \star}$ \\
\hline & $(0.7583)$ & $(0.0581)$ & $(0.7405)$ & $(0.0590)$ & $(0.4969)$ & $(0.0373)$ & $(0.6003)$ & $(0.0283)$ \\
\hline \multirow[t]{2}{*}{ BVPS $\times$ D } & 0.0862 & $0.4261^{\star *}$ & 0.1313 & $0.4250^{\star}$ & 0.3509 & $0.4060^{\star \star}$ & 0.2020 & $0.5514^{\star \star}$ \\
\hline & $(0.7825)$ & $(0.0382)$ & $(0.7154)$ & $(0.0677)$ & $(0.3484)$ & $(0.0373)$ & $(0.4525)$ & $(0.0156)$ \\
\hline \multirow[t]{2}{*}{$E P S \times D$} & -0.1932 & $-1.2309^{\star \star \star}$ & -0.4271 & $-1.0899^{\star *}$ & 0.0257 & -0.7738 & 0.1417 & $-0.9872^{\star}$ \\
\hline & $(0.8158)$ & $(0.0083)$ & $(0.6481)$ & $(0.0173)$ & $(0.9809)$ & $(0.1279)$ & $(0.9071)$ & $(0.0536)$ \\
\hline \multirow[t]{2}{*}{ Constant } & $0.6404^{\star \star \star}$ & $0.7001^{\star \star \star}$ & $0.6251^{\star * *}$ & $0.6821^{\star \star \star}$ & $0.6314^{\star \star *}$ & $0.6801^{\star \star \star}$ & $0.6267^{\star \star \star}$ & $0.6828^{\star \star \star}$ \\
\hline & $(0.0017)$ & $(0.0003)$ & $(0.0014)$ & $(0.0003)$ & $(0.0010)$ & $(0.0003)$ & $(0.0005)$ & $(0.0002)$ \\
\hline Observations & 2,329 & 2,329 & 2,329 & 2,329 & 2,329 & 2,329 & 2,329 & 2,329 \\
\hline R-squared & 0.755 & 0.758 & 0.755 & 0.757 & 0.755 & 0.756 & 0.755 & 0.757 \\
\hline Firm FE & Yes & Yes & Yes & Yes & Yes & Yes & Yes & Yes \\
\hline Year FE & Yes & Yes & Yes & Yes & Yes & Yes & Yes & Yes \\
\hline
\end{tabular}

Notes: The dependent variable of each regression is stock price measured after 3 months from the fiscal year-end. Panels $A, B, C$, and D present outcomes obtained for dividing the entire sample into $2,3,4$, and 5 equal subsamples based on the current ratio and the OCF ratio. The first (second) column of each panel documents outcomes for the interaction term between accounting items and the low-liquidity dummy obtained for the current (OCF) ratio. BVPS, EPS, CUR_R, and OCF_R, respectively, refer to book value of equity, earnings, current ratio, and operating cash flow ratio. All variables, except for dummies, are deflated by total assets. Firm-fixed and year-fixed effects are controlled. P-values in parentheses.

${ }^{\star \star \star} p<0.01,{ }^{\star *} p<0.05,{ }^{\star} p<0.1$.

Table 2 : the current ratio-based low liquidity does not lead to significant changes in valuation multiples of accounting figures, whereas the CFO ratio-based low liquidity does lead to such changes.

Overall, all these outcomes confirm our hypotheses: from the perspective of FHH, the OCF ratio is a more convenient indicator of the liquidity dimension of financial health than the current ratio. In other words, the OCF ratio is considered a more real liquidity measure by the market. Our outcomes further give a solid ground to Mills and Yamamura's [1998] argument that the liquidity condition of a firm is more reliably reflected by CFS than by the other indicators.

\section{Conclusion}

Liquidity ratios are one of the measures of financial health [Joseph, 2013]. Therefore, lower liquidity ratios imply lower financial health. In this study, from the perspective of $\mathrm{FHH}$, we analyze whether the current ratio, which is the reflection of accrual-based accounting rules, or the OCF ratio, which is the reflection of cash-based accounting rules, is a good proxy for the liquidity dimension of financial health. By following Barth et al. [1998] and Dhaliwal et al. [2010], we first divide the whole sample into two based on the median current ratio and OCF ratio. Thereafter, we perform our analyses to unravel how the valuation multiples of accounting figures change for the lowest liquidity subsamples. We also divide the whole sample into three, four, and five equal subsamples based on these two liquidity ratios as further analyses.

By employing a sample of Turkish listed firms during 2009-2018, we document that (i) valuation multiples of accounting figures remain unchanged for the lowest liquid subsample obtained for the current 
ratio and (ii) the valuation multiple of book value of equity significantly increases while the valuation multiple of earnings significantly decreases for the low-liquid subsample obtained for the OCF ratio. In other words, the value relevance of financial reporting items significantly differs if observations are grouped based only on the OCF ratio. Outcomes reported for the OCF ratio-based low liquidity are in line with FHH and with the literature [Barth et al., 1998; Dhaliwal et al., 2010], whereas statistically insignificant impacts reported for the current ratio-based low liquidity are not. From the perspective of $\mathrm{FHH}$, it is inferred that the market considers the OCF ratio, which is cash-based and dynamic, as a more appropriate proxy for the liquidity dimension of financial health than the current ratio, which is accrual-based and static. These findings support the argument of Mills and Yamamura [1998]: CFS conveys a more reliable message about the liquidity of a firm than traditional static financial statements.

Our study provides significant insights for creditors, equity investors, and regulatory authorities. Creditors check the liquidity of the borrower by monitoring the current ratio, which is one of the most frequently used debt covenant measures [Chava and Roberts, 2008]. Our study points out that, as a liquidity measure, the market does not consider the current ratio; it considers the OCF ratio instead. Creditors may consider adding the OCF ratio as a liquidity covenant to credit agreements. As this ratio shows the division of a sum (OCF) by another sum (current liabilities), it is easy to understand and calculate. Moreover, it does not carry accrual-based accounting judgments compared to the current ratio, to some degree. Furthermore, our outcomes should be of interest to investors using financial statements-based valuation models, since they reveal that accounting items are valued differently for low-liquidity (measured by the OCF ratio) firms. Last, new standard issues or existing standard amendments may be designed by considering our outcomes to increase the liquidity information content of the current ratio.

Future research may analyze firms from many jurisdictions to present more generalizable outcomes. We limit the sample with one jurisdiction, since we do not want our outcomes to be affected by incomplete data provided by international data vendors, which significantly restricts generalizability [Siekkinen, 2016], and since we want to mitigate country-specific risks which are irrelevant to financial reporting [Bartov et al., 2005; Barth et al., 2008]. Also, we pick only one dimension of financial health in line with our research question, which may induce classification errors in identifying financially healthy and unhealthy subgroups. This is another caveat of our study. We hope that all these limitations and our findings will encourage researchers to document further evidence for this subject.

\section{References}

Al-Attar, A., Hussein, S. (2004), Corporate data and future cash flows, Journal of Business Finance \& Accounting, Vol. 31, No. 7-8, pp. 861-903.

André, P., Dionysiou, D., Tsalavoutas, I., André, P. (2018), Mandated disclosures under IAS 36 impairment of assets and IAS 38 intangible assets: value relevance and impact on analysts' forecasts, Applied Economics, Vol. 50, No. 7, pp. 707-725.

Barth, M.E., Beaver, W.H., Landsman, W.R. (1996), Valuation Characteristics of Equity Book Value and Net Income: Tests of the Abandonment Option Hypothesis, Working Paper, Stanford University.

Barth, M.E., Beaver, W.H., Landsman, W.R. (1998), Relative valuation roles of equity book value and net income as a function of financial health, Journal of Accounting and Economics, Vol. 25, No. 1, pp. 1-34.

Barth, M.E., Landsman, W.R., Lang, M.H. (2008), International accounting standards and accounting quality, Journal of Accounting Research, Vol. 46, No. 3, pp. 467-498.

Bartov, E., Goldberg, S.R., Kim, M. (2005), Comparative value relevance among German, U.S., and international accounting standards: a German stock market perspective, Journal of Accounting, Auditing \& Finance, Vol. 20, No. 2, pp. $95-119$.

Beaver, W.H. (2002), Perspectives on recent capital market research, Accounting Review, Vol. 77, No. 2, pp. $453-474$.

Btach, J. (2010), Financial risk identification based on the balance sheet information, in: 8th International Scientific Conference on Managing and Modeling of Financial Risk, Technical University of Ostrava, Ostrava, pp. 10-19.

Borsa Istanbul. (2018), Annual Integrated Report, retrieved from https://www.borsaistanbul.com/docs/default-source/ kurumsal-yonetim/borsa-2018-annual-report.pdf?sfvrsn=12.

Burgstahler, D.C., Dichev, I.D. (1997), Earnings, adaptation and equity value, The Accounting Review, Vol. 72, No. 2, pp. 187-215. 
Cagle, M.N., Kaytmaz Balsarı, Ç., Dalkılıç, A.F. (2015), Have we really been using the International Financial Reporting Standards (IFRS) since 2005? Case of Turkey, International Journal of Social Sciences and Humanity Studies, Vol. 7 , No. 1, pp. 36-46.

Chalmers, K., Clinch, G., Godfrey, J.M. (2008), Adoption of international financial reporting standards: impact on the value relevance of intangible assets, Australian Accounting Review, Vol. 18, No. 3, pp. 237-247.

Chava, S., Roberts, M.R. (2008), How does financing impact investment? The role of debt covenants, The Journal of Finance, Vol. 63, No. 5, pp. 2085-2121.

Chong, K.W. (2012), Prediction of operating cash flows using accrual based and cash-based accounting information among Malaysian Industrial Corporations, DBA thesis, Southern Cross University.

Crockett, A. (2008), Market liquidity and financial stability, Banque de France, Financial Stability Review, Vol. 11, pp. 13-17.

Dechow, P.M., Richardson, S.A., Sloan, R.G. (2008), The persistence and pricing of the cash component of earnings, Journal of Accounting Research, Vol. 46, No. 3, pp. 537-566.

Demir, V., Bahadır, O. (2007), Muhasebe Manipülasyonu, Mali Çözüm, Vol. 17, No. 84, pp. 103-119.

Dhaliwal, D.S., Li, O.Z., Xie, H. (2010), Institutional investors, financial health, and equity valuation, Asia-Pacific Journal of Accounting and Economics, Vol. 17, No. 2, pp. 151-173.

Diamond, J. (2002), Performance Budgeting-Is Accrual Accounting Required? No. WP/02/40, IMF Working Paper.

Dichev, I.D., Skinner, D.J. (2002), Large-sample evidence on the debt covenant hypothesis, Journal of Accounting Research, Vol. 40, No. 4, pp. 1091-1123.

Elliott, B., Elliott, J. (2013), Financial accounting and reporting, 13th edn, Pearson Education, Essex.

Ertuğrul, M. (2019), A review of the literature on IFRS adoption from the perspective of the value relevance, in: H. Dincer, S. Yüksel, (Eds), Handbook of research on global issues in financial communication and investment decision making, IGI Global, pp. 367-394.

Ertuğrul, M., Demir, V. (2018), How does unobserved heterogeneity affect value relevance? Australian Accounting Review, Vol. 28, No. 2, pp. 288-301.

Francis, J., Schipper, K. (1999), Have financial statements lost their relevance? Journal of Accounting Research, Vol. 37, No. 2, pp. 319-352.

Gómez-Rodríguez, L.M., Muiño, F., Lamas, F.R. (2012), Do investing cash flows help in explaining future corporate performance? Spanish Journal of Finance and Accounting/Revista Española de Financiación y Contabilidad, Vol. 41, No. 154, pp. 185-208.

Gow, I.D., Ormazabal, G., Taylor, D.J. (2010), Correcting for cross-sectional and time-series dependence in accounting research, Accounting Review, Vol. 85, No. 2, pp. 483-512.

Hayn, C. (1995), The information content of losses, Journal of Accounting and Economics, Vol. 20, pp. 125-153.

Hertenstein, J.H., McKinnon, S.M. (1997), Solving the puzzle of the cash flow statement, Business Horizons, Vol. 40, No. 1, pp. 69-77.

Joseph, C. (2013), Advanced credit risk analysis and management, John Wiley \& Sons, Croydon.

Kothari, S.P. (2001), Capital Markets Research in Accounting, Journal of Accounting and Economics, Vol. 31, pp. $105-231$.

Kvaal, E., Nobes, C. (2010), International differences in IFRS policy choice: a research note, Accounting and Business Research, Vol. 40, No. 2, pp. 173-187.

Lev, B. (2003), Corporate earnings: facts and fiction investors, The Journal of Economic Perspectives, Vol. 17, No. 2, pp. $27-50$. Mills, J.R., Yamamura, J.H. (1998), The power of cash flow ratios, Journal of Accountancy, Vol. 186, No. 4, pp. 53-61.

Ohlson, J.A. (1995), Earnings, book values, and dividends in equity valuation, Contemporary Accounting Research, Vol. 11, No. 2, pp. 661-687.

Onali, E., Ginesti, G., Vasilakis, C. (2017), How should we estimate value-relevance models? Insights from European data, British Accounting Review, Vol. 49, No. 5, pp. 460-473.

Richards, V.D., Laughlin, E.J. (1980), A cash conversion cycle approach to liquidity analysis, Financial Management, Vol. 9, No. 1, pp. 32-38.

Siekkinen, J. (2016), Value relevance of fair values in different investor protection environments, Accounting Forum, Vol. 40, No. 1, pp. 1-15.

Tibor, T., Veronika, F. (2011), Liquidity management and corporate risk, in: 7th Edition of the International Conference, Oradea, pp. 1161-1167.

Wyatt, A. (2008), What financial and non-financial information on intangibles is value-relevant? A review of the evidence, Accounting and Business Research, Vol. 38, No. 3, pp. 217-256.

Wysocki, P.D. (2009), Assessing earnings and accruals quality: US and international evidence, Working Paper, MIT Sloan School of Management.

Xu, W., Davidson, R.A., Cheong, C.S. (2017), Converting financial statements: operating to capitalised leases, Pacific Accounting Review, Vol. 29, No. 1, pp. 34-54. 